\section{PENGARUH PADAT TEBAR TINGGI TERHADAP KUALITAS AIR DAN PERTUMBUHAN IKAN MAS (CYPRINUS CARPIO) DENGAN PENAMBAHAN NITROBACTER}

\section{EFFECT OF HIGH STOCKING DENSITY WATER QUALITY AND GROWTH OF GOLDFISH (CYPRINUS CARPIO) WITH THE ADDITION NITROBACTER}

\author{
Eti Rutmawati Sihite1, Rosmaiti², Andika Putriningtias' ${ }^{3}$, Agus Putra AS ${ }^{4}$ \\ 1Prodi Akuakultur Fakultas Pertanian Universitas Samudra, Aceh \\ 2Prodi Agroteknologi Fakultas Pertanian Universitas Samudra Langsa, Aceh \\ 3 Prodi Akuakultur Fakultas Pertanian Universitas Samudra, Aceh \\ e-mail: etisihite@gmail.com
}

\begin{abstract}
Abstrak: Padat penebaran yang tinggi, mengakibatkan ruang gerak ikan menjadi sempit sehingga kompetisi terhadap oksigen dan pakan meningkat, akibatnya pertumbuhan ikan akan terhambat dan dapat menurunkan kualitas air. Salah satu upaya untuk menanggulangi masalah tersebut yaitu pengelolaan lingkungan budidaya dengan penambahan nitrobacter pada media pemeliharaan. Penelitian ini merupakan penelitian eksperimental, dengan menggunakan Rancangan Acak Lengkap (RAL) dengan 4 perlakuan dan 5 ulangan selama 40 hari. Perlakuan yang digunakan : A1: 15 ekor/ wadah, A2 : 20 ekor/wadah, A3 : 25 ekor/wadah, A4 : 30 ekor/wadah. Hasil penelitian menunjukkan bahwa kepadatan yang berbeda memberikan pengaruh yang sangat nyata $(\mathrm{P}<0,05)$ terhadap tingkat kelangsungan hidup ikan mas (SR), laju pertumbuhan harian $(\mathrm{LPH})$, berpengaruh nyata $(\mathrm{P}<0,05)$ terhadap laju pertumbuhan bobot mutlak dan tidak berbeda nyata $(P>0,05)$ terhadap laju pertumbuhan panjang mutlak. Kepadatan yang memberikan tingkat kelangsungan hidup (SR) terbaik pada perlakuan A1 (96,0 \%), laju pertumbuhan harian (LPH) terbaik pada perlakuan A1 (1,07 gr), laju pertumbuhan bobot mutlak terbaik pada perlakuan A1 (7,4 gr), laju pertumbuhan panjang mutlak terbaik pada perlakuan A1, A4 $(0,4 \mathrm{~cm})$. Hasil pengamatan kualitas air menunjukkan suhu $\left(29,6-29,7^{\circ} \mathrm{C}\right), \mathrm{DO}(6,7-6,9), \mathrm{pH}(6,5-6,7)$, Nitrit (0,001), Nitrat (3,5-7,5), Amonia (0,25-2,25 ppm).
\end{abstract}

Kata kunci : Ikan mas, nitrobacter, padat tebar, pertumbuhan

\begin{abstract}
High stocking density, resulting in a narrow space for fish so that competition for oxygen and feed increases, consequently fish growth will be hampered and can reduce water quality. One effort to overcome these problems is the management of the cultivation environment by adding nitrobacter to the maintenance media. This study is an experimental study, using a completely randomized design (CRD) with 4 treatments and 5 replications for 40 days. The treatments used: A1: 15 heads / container, A2: 20 heads / container, A3: 25 heads / container, A4: 30 heads / container.The results showed that different densities had a very significant effect $(P<0.05)$ on carp survival rate $(S R)$, daily growth rate $(L P H)$, and significant effect $(P<0.05)$ on absolute weight growth rate and not significantly different $(P>0.05)$ to the absolute length growth rate. Density that gives the best survival rate (SR) in the A1 treatment (96.0\%), the best daily growth rate (LPH) in the A1 treatment $(1.07 \mathrm{gr})$, the best absolute weight growth rate in the A1 treatment (7.4 gr ), the absolute best length growth rate for A1, A4 $(0.4$ $\mathrm{cm})$ treatments. Water quality observations showed temperature $\left(29.6-29.7^{\circ} \mathrm{C}\right), \mathrm{DO}(6.7-6.9), \mathrm{pH}(6.5$ 6.7), Nitrite (0.001), Nitrate (3.5- 7.5), Ammonia (0.25-2.25 ppm).
\end{abstract}

Keywords: Goldfish, nitrobacter, stocking density, growth 


\section{PENDAHULUAN}

Ikan mas (Cyprinus carpio) adalah salah satu jenis ikan air tawar yang disukai oleh masyarakat karena rasanya yang enak dan memiliki nilai gizi yang tinggi. Seiring berkembangnya pengetahuan masyarakat terhadap pentingnya sumber protein yang berasal dari ikan, maka dari itu kebutuhan ikan konsumsi dari tahun ke tahun semakin meningkat seiring bertambahnya jumlah penduduk (Rudiyanti and Ekasari 2009).

Budidaya ikan mas memiliki peranan penting dalam meningkatkan produksi perikanan untuk memenuhi kebutuhan pangan dan gizi, memperluas kesempatan kerja, meningkatkan pendapatan dan kesejahteraan petani ikan. Dikalangan petani maupun masyarakat, ikan mas telah banyak dibudidayakan karena tempatnya lebih mudah dijangkau yaitu pada sawah, kolam, dan air deras. Ikan mas juga dapat dikembangbiakkan hanya dengan perbaikan lingkungan atau manipulasi lingkungan (Tilahwati, 2015).

Ekskresi ikan berasal dari katabolisme protein pakan dan dikeluarkan dalam bentuk amonia dan urea yang berbahaya bagi ikan. Secara biologis, dialam dapat terjadi perombakan amonia menjadi nitrat (NO3), suatu bentuk yang tidak berbahaya dalam proses nirifikasi, terutama bakteri Nitrosomonas dan Nitrobacter (Kordi, 2012).

Nitrobakter merupakan bakteri nitrifikasi karena merupakan bakteri yang mengubah nitrit menjadi nitrat. Nitrobakter memiliki $\mathrm{pH}$ optimum antara 7,3-7,5, tumbuh pada optimal pada suhu $38^{\circ} \mathrm{C}$. Nitrobacter termasuk bakteri aerob, pada umumnya berbentuk batang, seperti pir atau pleomorfhic dan berkembang biak dengan budding (Grundman et al. 2000). Peranan bakteri Nitrobacter pada lingkungan akuakultur yaitu sebagai pengelolaan senyawa amoniak, biodegradasi limbah tambak, dan penambahan pada pakan ikan. Adapun tujuan dari penelitian yaitu untuk mengetahui pengaruh padat tebar tinggi terhadap pertumbuhan ikan mas dengan penambahan Nitrobacter.

\section{METODOLOGI}

Penelitian ini dilaksanakan selama 40 hari di Green House, Fakultas Pertanian, Universitas Samudra. Penelitian dilakukan dengan Rancangan Acak Lengkap (RAL), dengan empat perlakuan. Dan masing-masing perlakuan menggunakan 5 kali pengulangan Perlakuan A: padat tebar 15 ekor/30 L; Perlakuan B: padat tebar 20 ekor/30 L; Perlakuan C: padat tebar 25 ekor/30 L dan Perlakuan D: padat tebar 30 ekor/30 L.

Pengamatan ikan yang mati dilakukan setiap hari dengan mencatat jumlahnya. Derajat kelangsungan hidup dihitung menggunakan rumus (Effendi, 1979), sebagai berikut :

$$
\mathrm{SR}=\frac{N t}{N o} \boldsymbol{x} \mathbf{1 0 0} \%
$$

\section{Keterangan :}

SR : derajat kelangsungan hidup (survival rate) (\%)

Nt : jumlah ikan yang hidup pada akhir pemeliharaan (ekor)

No: jumlah ikan yang hidup pada awal pemeliharaan (ekor)

Pertumbuhan mutlak yaitu selisih dari bobot awal dengan bobot akhir. Pertumbuhan bobot dilakukan dengan mengambil seluruh benih ikan mas setiap wadah dan kemudian hasilnya dimasukkan ke dalam rumus (Huisman, 1987), sebagai berikut :

$$
\mathrm{W}=\mathrm{Wt}-\mathrm{Wo}
$$

\section{Keterangan :}

W : Pertumbuhan bobot mutlak (gram) (gram)

Wt: Bobot rata-rata pada akhir perlakuan (gram)

Wo: Bobot rata-rata pada awal perlakuan

Pertumbuhan panjang dilakukan dengan metode pengambilan sampling dengan mengambil seluruh benih ikan mas dari setiap wadah dan hasilnya dimasukkan dalam rumus (Zonneveld et al, 1991), sebagai berikut :

$$
\mathrm{L}=\mathrm{Lt}-\mathrm{Lo}
$$

Keterangan :

L : Pertumbuhan panjang mutlak (m)

Lt : Panjang rata-rata ikan pada akhir perlakuan (m)

$$
\text { perlakuan (m) }
$$

Lo : Panjang rata-rata pada awal

Menurut Takeuchi (1988), perhitungan laju pertumbuhan harian dapat dihitung dengan rumus :

$$
\mathrm{LPH}=\frac{\operatorname{LnW} t-\operatorname{LnWo}}{t} \boldsymbol{x} \mathbf{1 0 0} \%
$$

Keterangan : 
Wt: Bobot biomassa ikan uji pada akhir penelitian (g)

Wo: Bobot biomassa ikan uji pada awal penelitian (g)

t : Lama Penelitian (hari)

Parameter kualitas air media pemeliharaan ditentukan dengan mengukur parameter kualitas air selama penelitian yang terdiri daari parameter fisika dan kimia yang ditentukan yaitu $\mathrm{pH}$, amoniak, nitrit, nitrat, DO dan suhu. Pengukuran kualitas air akan dilakukan setiap 7 hari sekali. Data ini digunakan untuk menentukan kelayakan

\begin{tabular}{|c|c|}
\hline Perlakuan & Kelangsungan Hidup \\
\hline A1 & $96,0 \pm 2,62^{\mathrm{c}}$ \\
\hline A2 & $95,0 \pm 2,23^{\mathrm{c}}$ \\
\hline A3 & $86,4 \pm 2,99^{\mathrm{b}}$ \\
\hline A4 & $75,8 \pm 2,43^{\mathrm{a}}$ \\
\hline
\end{tabular}

Ket: Keterangan : Angka-angka yang diikuti oleh huruf yang sama tidak berbeda nyata menurut uji jarak berganda Duncan (DMRT) pada $\alpha=5 \%$

Tabel 2 menunjukkan bahwa hasil dari uji jarak berganda Duncan (DMRT) kelangsungan hidup tertinggi diperoleh pada perlakuan A1 yaitu sebesar 96,0\%,disusul oleh perlakuan A2 (95 \%) kemudian diikuti perlakuan A3 $(86,4 \%)$ dan paling rendah pada perlakuan $\mathrm{A} 4$ (75,8\%). Antara perlakuan A1 dan A2 secara statistik tidak berbeda nyata tetapi keduanya berbeda nyata dengan perlakuan A3 dan A4. kualitas air media pemeliharaan selama penelitian.

\section{HASIL}

Hasil analisis ragam menunjukkan bahwa pengaruh padat tebar tinggi memberikan pengaruh yang sangat nyata terhadap tingkat kelangsungan hidup ikan mas. Hasil uji jarak berganda Duncan tersaji pada tabel 2.

Tabel 2. Rata-rata Kelangsungan Hidup Ikan Mas 
Perbedaan pertumbuhan ikan mas dari masing -masing perlakuan diduga karena jumlah padat tebar benih ikan. Semakin tinggi jumlah padat tebar ikan, maka semakin lambat pertumbuhan ikan. Menurut Handjani dan Hastuti (2002) dalam Telaumbana (2018) yang menyatakan bahwa semakin tinggi kepadatan ikan maka akan mempengaruhi tingkah laku dan fisiologi ikan terhadap ruang gerak yang menyebabkan pertumbuhan, pemanfaatan makanan dan kelulushidupan mengalami penurunan.

\section{Laju Pertumbuhan Panjang Mutlak}

Hasil Uji Anova yang dilakukan pada penelitian menunjukkan bahwa pengaruh padat tebar tinggi terhadap pertumbuhan ikan mas (Cyprinus carpio) dengan penambahan nitrobacter pada media pemeliharaan memberikan pengaruh tidak nyata terhadap pertumbuhan panjang ikan mas.

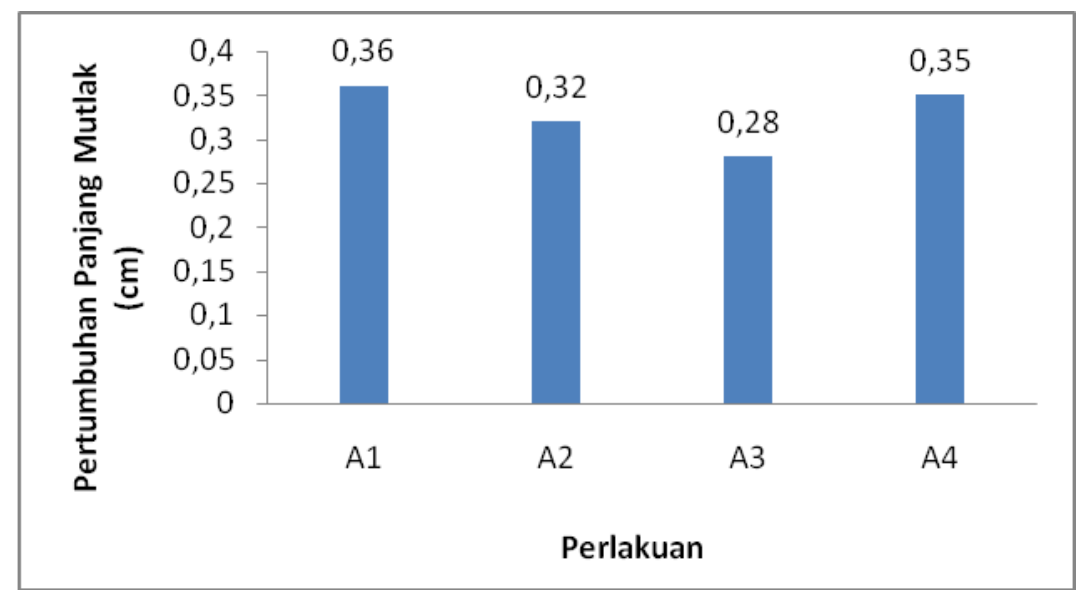

Gambar 1. Laju Pertumbuhan Panjang Mutlak Ikan Mas

Dapat dilihat pada Gambar 1 bahwa pertumbuhan panjang mutlak ikan mas tertinggi yaitu pada perlakuan A1 (15 ekor) sebesar 0,36 cm dan perlakuan A4 (30 ekor) sebesar 0,35 cm, kemudian diikuti perlakuan A2 (20 ekor) sebesar $0,32 \mathrm{~cm}$ dan perlakuan A3 (25 ekor) sebesar $0,28 \mathrm{~cm}$. Tingginya nilai ratarata laju pertumbuhan panjang mutlak pada perlakuan A1 diduga karena rendahnya padat tebar ikan dalam wadah budidaya sehingga tidak ada mortalitas pada wadah perlakuan A1. Hal ini juga disebabkan oleh luasnya ruang gerak yang membuat ikan selalu bergerak dan menghabiskan energi yang berasal dari pakan.
Ikan yang selalu bergerak akan mempengaruhi tingkah laku dan fisiologi ikan yang dapat menyebabkan pertumbuhan panjang ikan. Menurut Weatherly dan Gill (1987) dalam Ali et al. (2005), pertumbuhan ikan dipengaruhi makanan, ruang dan aktifitas fisik.

\section{Laju Pertumbuhan Harian (LPH)}

Hasil analisis sidik ragam pada penelitian menunjukkan bahwa perbedaan padat tebar ikan mas memberikan pengaruh yang nyata terhadap laju pertumbuhan harian ikan mas dapat dilihat pada Tabel 4 .

Tabel 4. Rata-rata Laju Pertumbuhan Harian Ikan Mas

\begin{tabular}{|c|c|}
\hline Perlakuan & Laju Pertumbuhan Spesifik (gr) \\
\hline A1 & $1,07 \pm 0,08^{\mathrm{b}}$ \\
\hline A2 & $1,00 \pm 0,16^{\mathrm{b}}$ \\
\hline A3 & $0,59 \pm 0,19^{\mathrm{a}}$ \\
\hline A4 & $0,46 \pm 0,20^{\mathrm{a}}$ \\
\hline
\end{tabular}

Keterangan : Angka-angka yang diikuti oleh huruf yang sama tidak berbeda nyata menurut uji jarak berganda Duncan (DMRT) pada $\alpha=5 \%$ 
Berdasarkan Tabel 4 dapat diketahui bahwa hasil dari uji jarak berganda Duncan (DMRT) menunjukkan bahwa pertumbuhan bobot harian tertinggi terdapat pada perlakuan A1 yaitu sebesar 1,07 gram, diikuti oleh perlakuan A2 sebesar 1,00 gram, dan perlakuan A3 sebesar 0,59 gram dan pertumbuhan terendah terdapat pada perlakuan A4 sebesar 0,46 gram. Kepadatan yang berbeda pada setiap perlakuan memberikan pengaruh yang nyata terhadap laju pertumbuhan harian ikan mas, diduga karena adanya kompetisi ruang gerak dan pakan sehingga mengganggu proses pertumbuhan. Sesuai dengan pendapat Rahmat (2010), Anuar et al, (2011) dan Agus et al (2014) bahwa pada padat tebar yang tinggi, akan mengakibatkan ikan mempunyai daya saing yang tinggi dalam memanfaatkan makanan dan ruang gerak, sehingga akan mempengaruhi laju pertumbuhan harian ikan tersebut.

\section{Kualitas Air}

Kualitas air merupakan faktor penting yang menunjang keberhasilan suatu usaha budidaya. Selama penelitian pengukuran kualitas air meliputi suhu, pH, DO, nitrit, nitrat dan amoniak. Hasil nilai rata-rata kualitas air selama penelitian dapat dilihat pada tabel 4.3.

Tabel 5. Rata-rata Kisaran Kualitas Air Selama Penelitian.

\begin{tabular}{|c|c|c|c|c|c|}
\hline \multirow{2}{*}{ Parameter } & \multicolumn{4}{|c|}{ Perlakuan } & \multirow{2}{*}{ Sumber Kelayakan } \\
\hline & A1 & $\mathrm{A} 2$ & A3 & A4 & \\
\hline Suhu $\left({ }^{\circ} \mathrm{C}\right)$ & 29,7 & 29,6 & 29,7 & 29,7 & $14-38^{\circ} \mathrm{C}$ (Santoso, 1992) \\
\hline $\mathrm{DO}(\mathrm{mg} / \mathrm{L})$ & 6,9 & 6,8 & 6,7 & 6,8 & $>3$ mg/L (Kartamihardja, 1981) \\
\hline $\mathrm{pH}$ & 6,7 & 6,5 & 6,6 & 6,7 & 6,5-8,5 (Pescod, 1973) \\
\hline Nitrit (mg/L) & 0,001 & 0,001 & 0,001 & 0,001 & $\begin{array}{l}0,2 \mathrm{mg} / \mathrm{L} \text { (Perkasa dan } \\
\text { Hisomudin, 2003) }\end{array}$ \\
\hline Nitrat (mg/L) & 3,5 & 4 & 6,7 & 7,5 & $<50$ mg/L (Boham, 2004) \\
\hline Amonia (ppm) & 0,25 & 0,67 & 2,0 & 2,25 & $<2,4$ ppm (Chervinsky, 1982) \\
\hline
\end{tabular}

Pada Tabel 5 dapat dilihat bahwa nilai rata-rata suhu pada masa penelitian yaitu berkisar antara 29,6 oC - 29,7 oC. Kisaran suhu tersebut masih tergolong masih sesuai dan baik

\section{PEMBAHASAN}

Tabel 2 menunjukkan bahwa kelangsungan hidup terendah terdapat pada perlakuan A4 yaitu 75,8 \%, disebabkan karena pada perlakuan A4 memiliki padat tebar yang lebih tinggi yang menyebabkan kurangnya ruang gerak pada ikan di dalam wadah penelitian sehingga tingkat kematian ikan lebih besar. Hal ini sesuai dengan pernyataan Wedemeyer (1996), peningkatan padat penebaran akan mengganggu proses fisiologi dan tingkah laku ikan terhadap ruang gerak yang akhirnya menurunkan kondisi kesehatan dan fisiologis, pemanfaatan makanan, pertumbuhan dan kelangsungan hidup. untuk budidaya ikan mas, hal ini sesuai dengan yang dikemukakan oleh Makaminan (2011), bahwa kisaran suhu optimum bagi kehidupan ikan adalah antara 25-32 oC

Kematian ikan selama penelitian juga disebabkan karena keadaan habitat ikan yang kurang cocok dengan wadah penelitian yang hanya menggunakan sistem airasi. Hal ini sesuai dengan pernyataan Saputra (2011), ikan mas dapat berkembang pesat di kolam dengan sistem pengairannya yang mengalir, sawah, kakaban, dan sungai air deras.

Kisaran pH yang diperoleh selama penelitian untuk semua perlakuan berkisar antara 6,5 - 6,7. Nilai pH pada kisaran tersebut tergolong baik untuk budidaya ikan mas. Nilai $\mathrm{pH}$ yang baik untuk budidaya ikan mas berkisar 6,5 - 8,5 Kisaran pH yang diperoleh selama penelitian untuk semua perlakuan berkisar antara 6,5 - 6,7 (Wihardy, 2014). 
Berdasarkan hasil pengukuran selama melakukan penelitian, kadar oksigen terlarut yang didapatkan yaitu berkisar antara 6,7 - 6,9 mg/L. Menurut Swingle, (1968) yang menyatakan bahwa kandungan oksigen dalam suatu perairan minimum sebesar $2 \mathrm{mg} / \mathrm{L}$, sudah cukup mendukung terhadap organisme perairan secara normal. Kandungan amonia pada setiap perlakuan mengalami peningkatan yang cukup signifikan yaitu sebesar 0,25 - 2,25 ppm. Kandungan amonia tersebut masih dalam kisaran yang dapat ditoleransi untuk budidaya ikan mas. Hal ini sesuai dengan pendapat Chervinsky, (1982) kisaran konsentrasi amonia yang baik untuk kehidupan ikan adalah kurang dari 2,4 mg/L.

Kandungan nitrit dan nitrat yang diperoleh selama pemeliharaan benih, yaitu nitrit sebasar $0,001 \mathrm{mg} / \mathrm{L}$ dan nitrat berkisar

\section{KESIMPULAN}

Berdasarkan penelitian yang telah dilakukan dapat disimpulKan bahwa perbedaan padat penebaran ikan mas memberikan pengaruh yang sangat nyata terhadap tingkat kelangsungan hidup (Survival Rate), laju pertumbuhan harian (LPH), berpengaruh nyata terhadap laju pertumbuhan

\section{DAFTAR PUSTAKA}

Ali, M., F. Iqbal, A. Salam, S. Iram \& M. Athar, 2005. Comparative study of body composition of different fish speciesm from brackish water pond. int. J. Environ. Sci. Tech. 2(3): 229-232.

Agus Putra A Samad, Nan Fan Hua, Lee Meng Chou. 2014. Effects of stocking density on growth and feed utilization of grouper (Epinephelus coioides) reared in recirculation and flow-through water system. African Journal of Agricultural Research. 9 (9): 812-822.

Anuar Hassan, Mohd Azmi Ambak, Agus Putra A Samad. 2011. Crossbreeding of Pangasianodon hypophthalmus (Sauvage, 1878) and Pangasius nasutus (Bleeker, 1863) and their larval development. Journal of Sustainability Science and Management. 6 (1): 28-35.

Chervinsky, J. 1982. Enviromental Physiology of Tilapia. In R. S. V. Pullin and R. H. Lowe. Mc Connel (Editors) The Biology and Culture of Tilapias. ICLARM Manila

Effendi, M.I. 1979. Metoda Biologi Perikanan. Yayasan Dewi Sri. Bogor. Hal : 112 antara 3,5 - 7,5 mg/L. Kandungan nitrit selama pemeliharaan tersebut masih dalam kisaran yang baik. Hal ini sesuai dengan pendapat Perkasa dan Hisomudin (2003) yang menyatakan bahwa normalnya kandungan nitrit terlarut di dalam air adalah $0,2 \mathrm{mg} / \mathrm{L}$ sedangkan kandungan nitrat yang baik yaitu 40 $\mathrm{mg} / \mathrm{L}$

Konsentrasi amonia, nitrit dan nitrat pada media pemeliharaan untuk setiap perlakuan selama penelitian relatif stabil pada kisaran yang dapat ditolerir oleh ikan. Resiko peningkatan konsentrasi amonia dalam air dapat dihindari dengan adanya penambahan nitrobacter pada media pemeliharaan. Dimana bakteri Nitrobacter akan mengubah nitrat menjadi nitrit sehingga lingkungan menjadi stabil (Taufik et al.2005).

bobot mutlak dan berpengaruh tidak nyata terhadap laju pertumbuhan panjang mutlak ikan mas (Cyprinus carpio). Padat penebaran optimal untuk budidaya ikan mas pada media pemeliharan adalah sebanyak 15 - 20 ekor/30 liter karena memberikan pertumbuhan dan sintasan yang lebih tinggi dibandingkan dengan padat tebar 30 - 35 ekor/30 liter.

Grundmann, G.L., M. Neyra, and P. Normand. 2000. High-resolution phylogenetic analysis of NO2 oxidizing Nitrobacter species using the rrs-rrl IGS sequence and rrl genes. International Journal Systematic and Evolutionay Microbiology 50: 18931898

Kordi, M.G. 2012. Kiat Sukses Pembesaran Lele Unggul, Lily Publisher. Yogyakarta.

Perkasa, B. E. dan Hisomudin, 2003. Permasalahan Mas Koki dan Solusinya. Penebar Swadaya. Jakarta

Rahmat, F. 2010. Pembenihan Ikan Koi (Cyprinus carpio) Di Kelompok Tani Sumber Harapan, Kabupaten Bliter, Provinsi Jawa Timur. Program Studi. Teknologi dan Manajemen Perikanan Budidaya Departemen Budidaya Perairan Fakultas Perikanan dan Ilmu Kelautan Institut Pertanian Bogor.

Rudiyanti, Siti, and Diana Ekasari. 2009. "Pertumbuhan Dan Survival Rate Ikan Mas ( Cyprinus Carpio Linn ) Pada Berbagai Konsentrasi Pestisida Regent 0 , 3 G Growth and Survival Rate of Cyprinus Carpio Linn Juvenile on Different Concentration of Regent 0 . 3 g Pesticide ." Jurnal Saintek Perikanan 5(1): 49-54. 
Saputra. S. 2011. Aplikasi Sistem Resirkulasi Air Terkendali (STRAT) pada Budidaya Ikan Mas (Cyprinus carpio)

Swingle, H.S. 1968. Standardization of Chemical Analysis for Water and Pond Muds. F.A.O. Fis, Rep. 44,4, 379-406 pp.

Taufik, I., H. Supriadi, I. Muthalib, P. Yulianti dan S. Subandiyah. 2005. Studi Pengaruh Suhu Air terhadap Aktivitas Bakteri Bioremediasi (Nitrosomonas dan Nitrobacter) pada Pemeliharaan Benih Ikan Patin Siam (Pangasius pothalamus). Jurnal Perikanan Indonesia. hal 59-66.

Telaumbanua, 2018. Pertumbuhan dan Kelulushidupan Ikan Lele Dumbo (Clarias sp.) Dengan Padat Tebar Berbeda Menggunakan Probiotik Boster Aquanenzyms Pada Pakan . Jurnal. Universitas Riau.

Tilahwati, Oki. 2015. "Manajemen Pembenihan Ikan Mas Punten (Cyprinus Carpio) Di Instalasi Budidaya Air Tawar, Punten, Batu, Malang Jawa Timur."

Wedemeyer, 1996. Growth and Ecology of Fish Populations. Academic Press. London

Wihardy Y, Yusanti IA, Haris RBK. 2014. Feminisasi pada ikan mas (Cyprinus carpio) dengan perendaman ekstrak daun tangkai buah Terung Cepoka (Solanum torvum) pada lama waktu perendaman berbeda. Jurnal Ilmu-ilmu Perikanan dan Budidaya Perairan Fakultas Perikanan, Universitas PGRI Palembang. Vol 9 No. 1: 23-28 